Neuro/mages

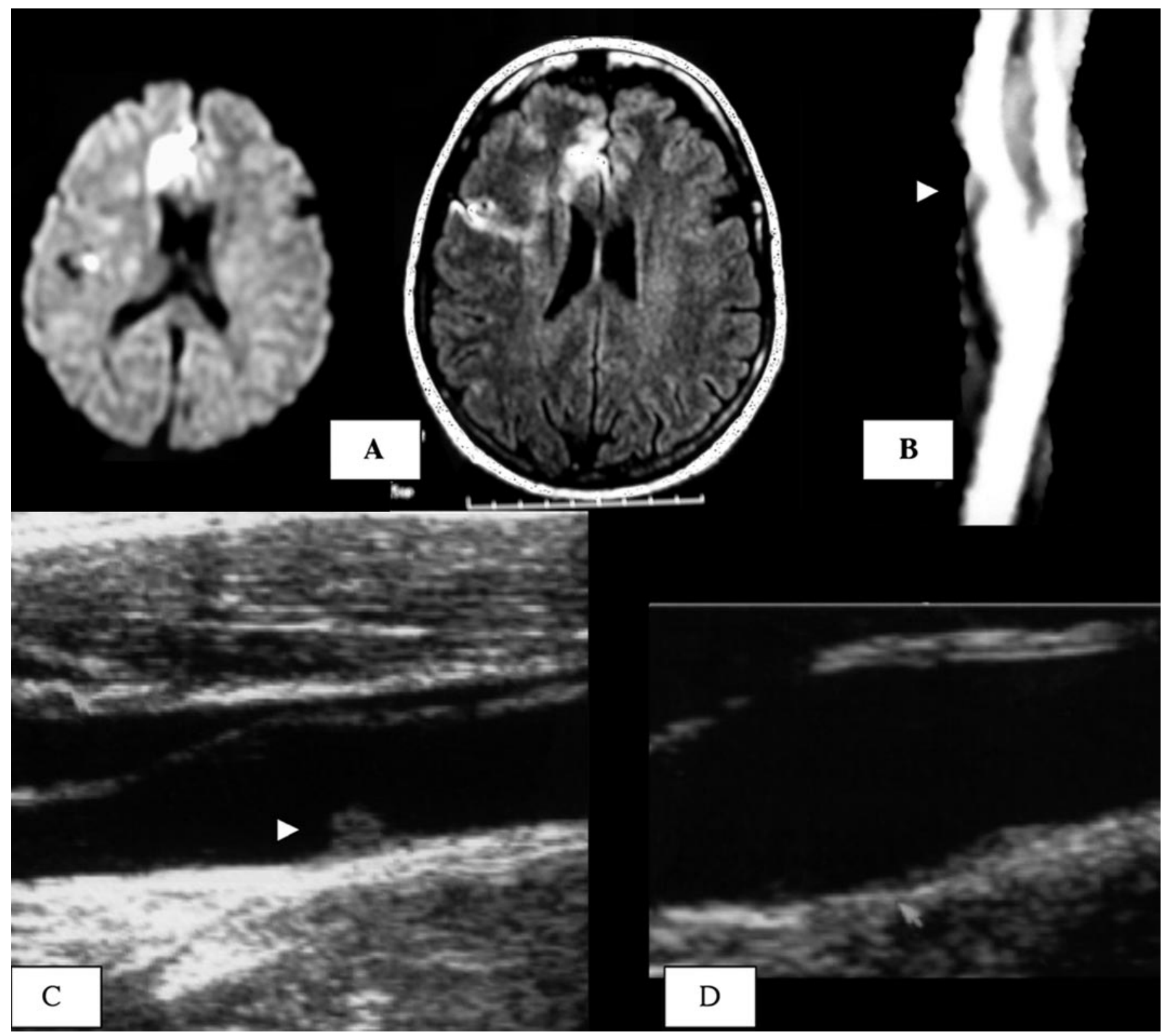

Figure. (A) Axial diffusion-weighted and fluid-attenuated inversion recovery (FLAIR) MRI: hyperintensity in right anterior and middle cerebral arteries; (B) mural thrombus of internal carotid artery (arrow) on CT scan-angiography and (C) cervical ultrasound; (D) control cervical ultrasound after 1 week.

\section{Thrombotic cocktail in stroke}

A. Idbaih, MD; I. Crassard, MD; K. Vahedi, $M D$;

J. P. Guichard, MD; and F. Woimant, MD, Paris, France

A 35-year-old woman was admitted after a sudden left-arm deficit, which was preceded by 3 weeks of the same transient episodes lasting less than 5 minutes each. She was being treated for menorrhagia with tranexamic acid and was also using oral contraceptives. Three weeks before, she had a Mycoplasma pneumoniae respiratory infection. MRI showed a recent ischemia in the territories of the right middle and anterior cerebral arteries (figure, A). Ultrasound examination and CT-scan-angiography re-

Address correspondence and reprint requests to Dr. Isabelle Crassard, Lariboisière hospital, 2 rue Ambroise Paré 75010, Paris, France; e-mail: isabelle.crassard@lrb.ap-hop-paris.fr vealed a mural thrombus of the right carotid internal artery (figure, B and C). After treatment with heparin, the patient completely recovered and the thrombus disappeared 1 week later (figure, D). Artery-artery emboli from carotid disease are one of the most common causes of stroke. Direct visualization of thrombus in the carotid artery is, however, uncommon, especially in patients without carotid disease. Tranexamic acid, inhibitor of fibrinolysis, and $M$ pneumoniae infection, in addition to oral contraceptives, were probably triggering factors in the formation of the carotid thrombus and its cerebral embolic complication. ${ }^{1,2}$

1. Dunn CJ, Goa KL. Tranexamic acid: a review of its use in surgery and other indications. Drugs 1999;57:1005-1032.

2. Sotgiu S, Pugliatti M, Rosati G, Deiana GA, Sechi GP. Neurological disorders associated with Mycoplasma pneumoniae infection. Eur J Neurol 2003;10:165-168. 


\section{Neurology}

Thrombotic cocktail in stroke

A. Idbaih, I. Crassard, K. Vahedi, et al. Neurology 2005;64;334

DOI 10.1212/01.WNL.0000142981.77895.C3

This information is current as of January 24, 2005

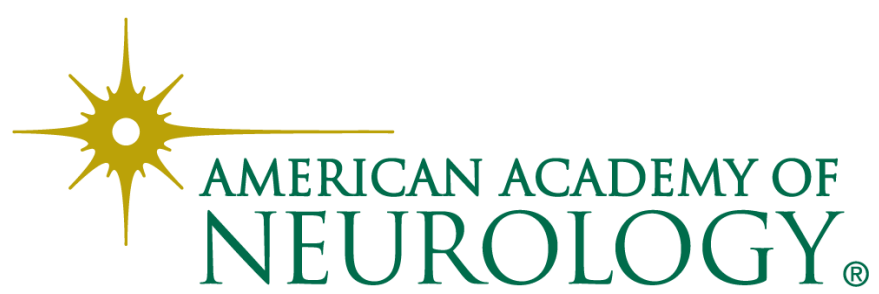




\section{Updated Information \&} Services

\section{Supplementary Material}

References

Citations

Subspecialty Collections

Permissions \& Licensing

Reprints including high resolution figures, can be found at:

http://n.neurology.org/content/64/2/334.full

Supplementary material can be found at:

http://n.neurology.org/content/suppl/2012/04/16/64.2.334.DC1

This article cites 2 articles, 0 of which you can access for free at: http://n.neurology.org/content/64/2/334.full\#ref-list-1

This article has been cited by 1 HighWire-hosted articles: http://n.neurology.org/content/64/2/334.full\#\#otherarticles

This article, along with others on similar topics, appears in the following collection(s):

\section{All Cerebrovascular disease/Stroke}

http://n.neurology.org/cgi/collection/all_cerebrovascular_disease_strok e

\section{All Clinical trials}

http://n.neurology.org/cgi/collection/all_clinical_trials

Clinical trials Observational study (Cohort, Case control)

http://n.neurology.org/cgi/collection/clinical_trials_observational_study cohort_case_control

\section{$\overline{\mathbf{D W I}}$}

http://n.neurology.org/cgi/collection/dwi

Infarction

http://n.neurology.org/cgi/collection/infarction

Information about reproducing this article in parts (figures,tables) or in its entirety can be found online at:

http://www.neurology.org/about/about_the_journal\#permissions

Information about ordering reprints can be found online:

http://n.neurology.org/subscribers/advertise

Neurology ${ }^{\circledR}$ is the official journal of the American Academy of Neurology. Published continuously since 1951, it is now a weekly with 48 issues per year. Copyright. All rights reserved. Print ISSN: 0028-3878. Online ISSN: 1526-632X.

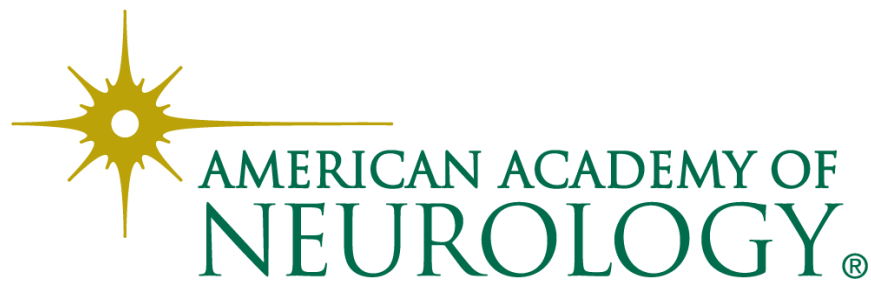

